\title{
Wpływ paliw estrowych na procesy utleniania oleju silnikowego w czasie eksploatacji
}

\begin{abstract}
W artykule przedstawiono wyniki badań oleju silnikowego w czasie eksploatacji podczas zasilania paliwami estrowymi i olejem napędowym. Obiektem badań był silnik samochodu AUDI A8 2.5 TDI pracujący na dystansie około $10000 \mathrm{~km}$. W trakcie badań określono proces utleniania oleju silnikowego podczas zasilania paliwami estrowymi i porównano go z procesem utleniania tego oleju podczas zasilania olejem napędowym. Otrzymane wyniki wskazują, że paliwa estrowe mają podobny wpływ na procesy utleniania oleju silnikowego w czasie eksploatacji jak olej napędowy.

Słowa kluczowe: paliwa zawierające RME, CME, olej napędowy, olej silnikowy, proces utleniania, badania eksploatacyjne.

\section{Influence of ester fuels on the oxidation processes of engine oil during the field tests}

The paper presents results of field tests of engine oil fuelled with ester fuels and diesel fuel. The field tests were conducted with an AUDI A8 2.5 TDI car at a distance of 10,000 km. During the tests with ester fuels, the oxidation process of engine oil was determined. The results were compared with the oxidation process of engine oil where diesel was the fuel. The results indicate, that the ester fuels have a similar effect as the diesel fuel, they didn't affect the oxidation process of the engine oil during the field tests.
\end{abstract}

Key words: fuels containing RME, CME, diesel fuel, engine oil, oxidation, field tests.

\section{Wprowadzenie}

Lnianka siewna jako roślina uprawna znana jest od bardzo dawna. Głównie uprawiano ją na terenach Europy Wschodniej i Azji Centralnej. Może rosnąć na mniej żyznych glebach niż rzepak, w tym na glebach lekkich. Uprawę lnianki siewnej można prowadzić w warunkach ekologicznych, tzn. bez stosowania pestycydów (herbicydów i insektycydów), na ziemiach V i VI kategorii z bardzo ograniczonym nawożeniem azotowym. Słabsze gleby (klasa V i VI) nie nadają się natomiast do uprawy rzepaku, bowiem wymaga on gleb głębokich, żyznych, zasobnych w próchnicę i wapń. Tak więc rzepak nie konkuruje z lnianką o tereny uprawne.

Mimo że lnianka nie ma tak dużych wymagań glebowych, najważniejszą rośliną oleistą uprawianą w Polsce jest rzepak, ponieważ ponad $40 \%$ masy jego nasion stanowi olej.

Z oleju lnicznikowego (lniankowego) można wytwarzać estry metylowe w podobny sposób jak z oleju rzepakowego. Należy jednak uwzględnić występujące różnice, które dotyczą zawartości substancji śluzowych, zawartości wolnych kwa- sów tłuszczowych oraz struktury chemicznej kwasów tłuszczowych związanych w postaci glicerydów. Świeżo tłoczony olej lniankowy zawiera zanieczyszczenia w postaci białek oraz części stałych [3]. Zwiększona zawartość substancji śluzowych obecnych w surowym oleju lnicznikowym utrudnia rozdział fazy estrowej od glicerynowej w procesie transestryfikacji. Z tego względu olej lnicznikowy stosowany do wytwarzania biodiesla musi być starannie odśluzowany przy zastosowaniu znanych metod $[1,4]$. Olej ten charakteryzuje się większą zawartością wolnych kwasów tłuszczowych, która dochodzi do około 5\%. Również ogólna zawartość substancji niezmydlających się w oleju z lnicznika siewnego jest duża i wynosi od $0,8 \%$ do 1,2\% [1]. Duża zawartość wolnych kwasów thuszczowych wymusza stosowanie efektywnych metod odkwaszania, w przeciwnym wypadku zwiększa się zużycie katalizatora transestryfikacji oraz powstają problemy z uzyskaniem estrów metylowych o wysokiej czystości. $\mathrm{W}$ tablicy 1 porównano skład chemiczny kwasów tłuszczowych, związanych w po- 
Tablica 1. Profil kwasów tłuszczowych zawartych w glicerydach z oleju lniankowego i rzepakowego

\begin{tabular}{|c|l|c|c|}
\hline Lp. & \multicolumn{1}{|c|}{ Rodzaj kwasu } & $\begin{array}{c}\text { Olej } \\
\text { lniankowy }\end{array}$ & $\begin{array}{c}\text { Olej } \\
\text { rzepakowy }\end{array}$ \\
\hline 1. & Kwas $\mathrm{C}_{10: 0}$ & 0,00 & 0,03 \\
\hline 2. & Kwas $\mathrm{C}_{12: 0}$ & 0,00 & 0,02 \\
\hline 3. & Kwas $\mathrm{C}_{14: 0}$ & 0,06 & 0,08 \\
\hline 4. & Kwasy $\mathrm{C}_{14}$ nienasycone & 0,00 & 0,00 \\
\hline 5. & Kwas $\mathrm{C}_{15: 0}$ & 0,00 & 0,22 \\
\hline 6. & Kwas $\mathrm{C}_{16: 0}$ & 5,69 & 0,29 \\
\hline 7. & Kwasy $\mathrm{C}_{16}$ nienasycone & 0,18 & 4,69 \\
\hline 8. & Kwas $\mathrm{C}_{17: 0}$ & 0,05 & 0,13 \\
\hline 9. & Kwas $\mathrm{C}_{18: 0}$ & 2,50 & 1,30 \\
\hline 10. & Kwasy $\mathrm{C}_{18: 1}$ & 11,87 & 56,50 \\
\hline 11. & Kwasy $\mathrm{C}_{18: 2}$ & 15,60 & 25,60 \\
\hline 12. & Kwasy $\mathrm{C}_{18: 3}$ & 39,00 & 6,56 \\
\hline 13. & Kwasy $\mathrm{C}_{20: 1}$ & 18,64 & 2,06 \\
\hline 14. & Kwas $\mathrm{C}_{20: 0}$ & 1,40 & 0,67 \\
\hline 15. & Kwas $\mathrm{C}_{22: 1}$ & 0,00 & 1,13 \\
\hline 16. & Kwas $\mathrm{C}_{22: 0}$ & 0,40 & 0,37 \\
\hline 17. & Kwas $\mathrm{C}_{22: 2}$ & 3,70 & 0,00 \\
\hline 18. & Kwas $\mathrm{C}_{24: 1}$ & 0,66 & 0,18 \\
\hline 19. & Kwas $\mathrm{C}_{24: 0}$ & 0,17 \\
\hline 20. & Inne & 0,00 \\
\hline
\end{tabular}

Źródło: [3]. krzepnięcia estrów metylowych. Zawartość kwasów $\mathrm{C}_{18}$ jednonienasyconych w oleju lniankowym jest 3,5-krotnie niższa niż w oleju rzepakowym. Obecność wielonienasyconych kwasów tłuszczowych zawartych w strukturze glicerydów oleju lniankowego jest korzystna, gdyż powoduje obniżenie temperatury krzepnięcia nie tylko samego oleju, ale również jego estrów metylowych, jednak z drugiej strony jest ona przyczyną ich stosunkowo małej odporności oksydacyjnej. W celu osiągnięcia żądanej stabilności biodiesla należy więc starannie dobrać rodzaj i ilość wprowadzanych antyutleniaczy. To wyraźne zróżnicowanie składu chemicznego porównywanych olejów wpływa na właściwości fizykochemiczne ich estrów metylowych, takie jak temperatura krzepnięcia czy stabilność oksydacyjna. Porównanie podstawowych właściwości fizykochemicznych oleju lniankowego i oleju rzepakowego przedstawiono w tablicy 2 .

Olej lniankowy cechuje się mniejszymi wartościami temperatury płynięcia i krzepnięcia od oleju rzepakowego. Spowodowane jest to dużo większą zawartością jednonienasyconych kwasów $\mathrm{C}_{20} \mathrm{~W}$ strukturze glicerydów zawartych w lniance siewnej. $Z$ tego względu należy rozważać polepszenie właściwości niskotemperaturowych biodiesla wyprodukowanego z lnianki siewnej na drodze winteryzacji (odwoskowania). Estry metylowe oleju lniankowego po tej operacji powinny się cechować znacznie lepszymi właściwościami niskotemperaturowymi od estrów wytworzonych z oleju rzepakowe- staci glicerydów, w oleju lniankowym i oleju rzepakowym [3].

Olej lniankowy w porównaniu z olejem rzepakowym charakteryzuje się znacznie większą zawartością kwasów thuszczowych o 3 wiązaniach nienasyconych w łańcuchu węglowodorowym. Z przeprowadzonych badań wynika, że zawartość tych kwasów wynosi ponad $38 \%$, podczas gdy w oleju rzepakowym około 9\% [3]. Olej lniankowy cechuje także znacznie większy udział kwasów tłuszczowych $\mathrm{C}_{20}$, bo okoto $18 \%$, podczas gdy w oleju rzepakowym znajduje się ich tylko około $2 \%$. Wpływa to na podwyższenie temperatury
Tablica 2. Właściwości fizykochemiczne surowego oleju lniankowego i oleju rzepakowego

\begin{tabular}{|l|c|c|c|}
\hline \multicolumn{1}{|c|}{ Właściwości } & Jednostka & Olej lniankowy & Olej rzepakowy \\
\hline Gęstość w temperaturze $20^{\circ} \mathrm{C}$ & $\mathrm{kg} / \mathrm{m}^{3}$ & 909 & 902 \\
\hline Temperatura płynięcia & ${ }^{\circ} \mathrm{C}$ & $-17,0$ & $-19,5$ \\
\hline Temperatura krzepnięcia & ${ }^{\circ} \mathrm{C}$ & $-18,0$ & $-21,0$ \\
\hline Lepkość dynamiczna w temperaturze $40^{\circ} \mathrm{C}$ & $\mathrm{mPa} \cdot \mathrm{s}$ & 30,9 & 30,6 \\
\hline Lepkość kinematyczna w temperaturze $40^{\circ} \mathrm{C}$ & $\mathrm{mm}^{2} / \mathrm{s}$ & 34,8 & 33,9 \\
\hline Zawartość fosforu & $\%$ & 0,35 & - \\
\hline Liczba kwasowa & $\mathrm{mg} \mathrm{KOH} / \mathrm{g}$ & 5,5 & 0,2 \\
\hline
\end{tabular}

Źródło: [3].

\section{Estry metylowe oleju Iniankowego i oleju rzepakowego}

Surowcem do produkcji estrów metylowych kwasów thuszczowych są thuszcze zwierzęce i oleje roślinne: olej słonecznikowy, olej bawełniany, olej sojowy, olej kukurydziany, olej lniankowy, olej rzepakowy (najczęściej stoso- go. Właściwość ta może być wykorzystana do otrzymywania $\mathrm{z}$ ich użyciem kompozycji paliwowych opartych na estrach metylowych tłuszczów zwierzęcych, które charakteryzują się szczególnie wysokimi wartościami temperatury krzepnięcia. 
śla się również jako alkoholizę bądź metanolizę. Właściwości produktów procesu transestryfikacji zależą od chemicznego składu oleju roślinnego i stopnia jego oczyszczenia, a także od użytego alkoholu i warunków procesu. Tak uzyskiwane estry metylowe oleju rzepakowego spełniają wymagania normy PN-EN 14214 we wszystkich parametrach fizykochemicznych.

Proces otrzymywania estrów metylowych oleju lniankowego jest bardzo podobny do wytwarzania estrów metylowych oleju rzepakowego. Estry metylowe oleju lniankowego uzyskiwano z oczyszczonego surowca thuszczowego. Oczyszczanie polegało na odśluzowaniu tłuszczu przy użyciu roztworu kwasu cytrynowego i na osuszeniu. Estry metylowe otrzymywano $\mathrm{w}$ dwuetapowym procesie transestryfikacji glicerydów metanolem w obecności katalizatora alkalicznego. Katalizatorem reakcji transestryfikacji glicerydów metanolem był roztwór wodorotlenku potasu w metanolu.
Wytworzone w taki sposób estry metylowe oleju lniankowego spełniały wymagania normy PN-EN $14214 \mathrm{w}$ zakresie parametrów takich jak suma estrów metylowych, liczba kwasowa oraz zawartość nieprzereagowanych glicerydów czy wolnego glicerolu. Spełnienie wszystkich formalnych wymagań normy przez czyste estry metylowe oleju lniankowego jako paliwa do silników wysokoprężnych jest niemożliwe do osiągnięcia ze względu na specyficzne właściwości wynikające ze składu surowca thuszczowego. Dotyczy to szczególnie dopuszczalnej wartości liczby jodowej, zawartości estrów metylowych kwasu linolenowego $\left(\mathrm{C}_{18: 3}\right)$ oraz w mniejszym zakresie temperatury blokady zimnego filtra [2].

Dlatego w badaniach eksploatacyjnych do zasilania silnika wysokoprężnego nie zastosowano czystych estrów metylowych oleju lniankowego, lecz kompozycję paliwową składającą się z estrów pochodzących z innych olejów i tłuszczów oraz odpowiednich dodatków.

\section{Badania eksploatacyjne}

Obiektem badań eksploatacyjnych był silnik z zapłonem samoczynnym samochodu AUDI A8 2.5 TDI o mocy $110 \mathrm{~kW}$.

Badania eksploatacyjne prowadzono dla trzech wymian oleju silnikowego. Po każdej wymianie oleju silnik zasilany był innym rodzajem paliwa.

Przy pierwszej wymianie oleju do zasilania silnika zastosowano paliwo badawcze składające się z 75\% estrów metylowych oleju rzepakowego, $15 \%$ estrów metylowych oleju lniankowego i 10\% estrów metylowych tłuszczów zwierzęcych oraz dodatków uszlachetniających: niskotemperaturowego, antykorozyjnego, antyutleniającego i biocydu. Przy drugiej wymianie wykorzystano paliwo zawierające w $100 \%$ estry metylowe oleju rzepakowego oraz dodatki uszlachetniające: niskotemperaturowy, antykorozyjny, antyutleniający i biocyd. Przy trzeciej wymianie silnik zasilany był natomiast olejem napędowym handlowym zawierającym około 7\% FAME.
W tablicy 3 przedstawiono właściwości fizykochemiczne paliw estrowych użytych do badań.

Obydwa paliwa estrowe spełniły wymagania normy PN-EN 14214 i mogły być przeznaczone do zasilania silnika podczas badań eksploatacyjnych. Również olej napędowy handlowy spełniał wymagania normy PN-EN 590. Silnik eksploatowanego pojazdu podczas badań smarowany był handlowym olejem silnikowym SAE 10W/40 ACEA A3/B3, API CF.

Badania eksploatacyjne dla każdego paliwa prowadzono na dystansie 10000 km, w jeździe miejskiej i pozamiejskiej, w zmiennych warunkach klimatycznych.

Próbki do badań pobierano zgodnie z opracowaną w Przemysłowym Instytucie Motoryzacji procedurą pobierania próbek oleju silnikowego z eksploatowanego pojazdu.

W czasie badań eksploatacyjnych i po ich zakończeniu pobrane próbki zostały poddane badaniom pod kątem
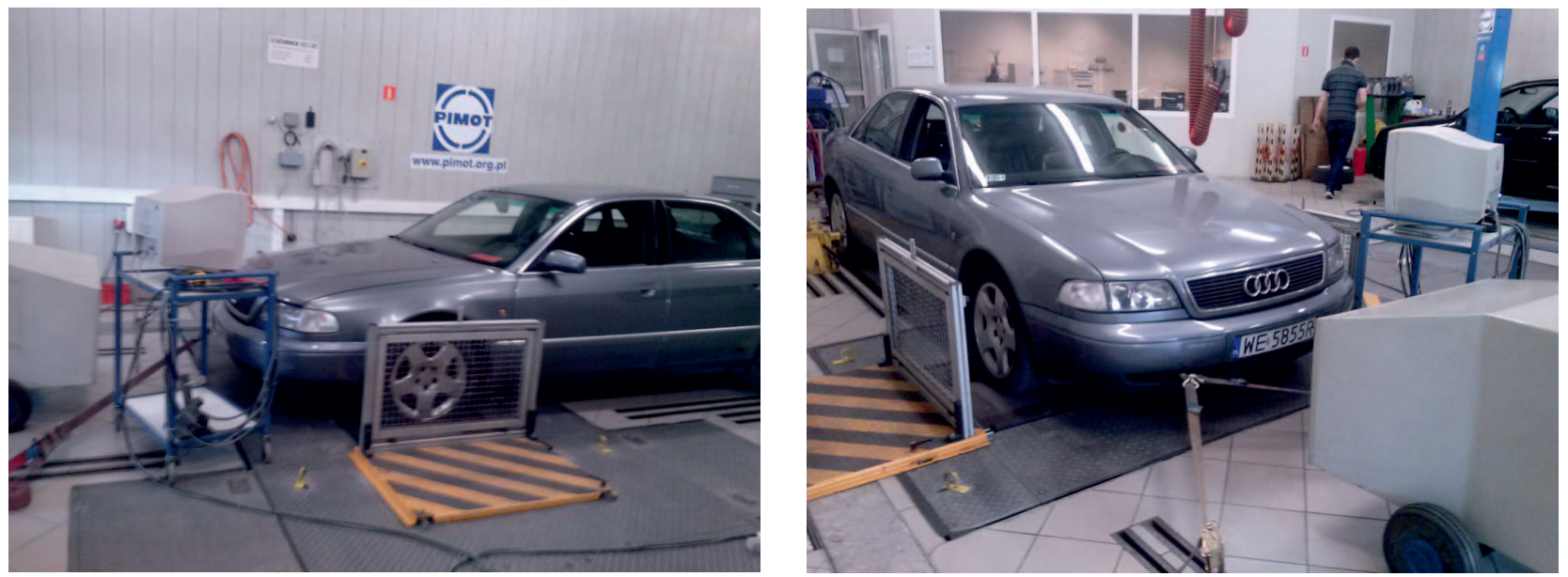

Rys. 1. Samochód osobowy AUDI A8 2.5 TDI 
Tablica 3. Właściwości fizykochemiczne paliw estrowych

\begin{tabular}{|c|c|c|}
\hline Rodzaj kwasu & Paliwo - kompozycja estrów & Paliwo - $100 \%$ RME \\
\hline Zawartość estrów metylowych wyższych kwasów tłuszczowych $[\%(\mathrm{~m} / \mathrm{m})]$ & 97,8 & 97,9 \\
\hline Gęstość w $15^{\circ} \mathrm{C}\left[\mathrm{kg} / \mathrm{m}^{3}\right]$ & 883,2 & 883,0 \\
\hline Lepkość kinematyczna w $40^{\circ} \mathrm{C}$ & 4,455 & 4,444 \\
\hline Temperatura zapłonu $\left[{ }^{\circ} \mathrm{C}\right]$ & 180 & 180 \\
\hline Popiół siarczanowy [\% $(\mathrm{m} / \mathrm{m})]$ & $<0,005$ & $<0,005$ \\
\hline Badanie działania korodującego na miedzi $\left(3 \mathrm{~h}, 50^{\circ} \mathrm{C}\right)$ [klasa $]$ & $1 \mathrm{a}$ & 1a \\
\hline Zawartość wody $[\mathrm{mg} / \mathrm{kg}]$ & 220 & 150 \\
\hline Zawartość zanieczyszczeń stałych [mg/kg] & 23,8 & $<12$ \\
\hline Stabilność oksydacyjna w $110^{\circ} \mathrm{C}[\mathrm{h}]$ & 7,4 & 8,6 \\
\hline Liczba cetanowa & 58,4 & 56,3 \\
\hline Zawartość siarki [mg/kg] & 0,5 & 1,5 \\
\hline Pozostałość po koksowaniu (z 10\% pozost. destylacyjnej) $[\%(\mathrm{~m} / \mathrm{m})]$ & 0,23 & 0,16 \\
\hline Liczba kwasowa [mg KOH/g] & 0,43 & 0,32 \\
\hline Liczba jodowa [g jodu/100 g] & 95 & 99 \\
\hline Zawartość estru metylowego kwasu linolenowego [\% $(\mathrm{m} / \mathrm{m})]$ & 11,9 & 8,2 \\
\hline Zawartość metali grupy I $(\mathrm{Na}+\mathrm{K})[\mathrm{mg} / \mathrm{kg}]$ & 0,5 & 2,9 \\
\hline Zawartość metali grupy II $(\mathrm{Ca}+\mathrm{Mg})[\mathrm{mg} / \mathrm{kg}]$ & 0,3 & $<1,2$ \\
\hline Zawartość fosforu $[\mathrm{mg} / \mathrm{kg}]$ & $<0,1$ & $<4,0$ \\
\hline Temperatura zablokowania zimnego filtra $\left[{ }^{\circ} \mathrm{C}\right]$ & -9 & -20 \\
\hline
\end{tabular}

Źródło: Przemysłowy Instytut Motoryzacji.

zmian zachodzących we właściwościach fizykochemicznych w czasie eksploatacji w odniesieniu do oleju pobranego po wymianie oleju i pracy silnika przez 40 minut na biegu jałowym.

W trakcie badań monitorowano także:
- zachowanie się pojazdu i silnika w czasie eksploatacji,

- zużycie paliwa przez pojazd uczestniczący w badaniu,

- stan oleju silnikowego.

Po każdej zmianie paliwa wymieniano olej silnikowy oraz filtry: oleju, powietrza i paliwa.

\section{Wyniki badań eksploatacyjnych}

Wybrane parametry fizykochemiczne oleju silnikowego w trakcie badań eksploatacyjnych podczas zasilania paliwami estrowymi i olejem napędowym przedstawiono na rysunkach 2-9.

Eksploatacja samochodu osobowego AUDI A8 podczas zasilania paliwami estrowymi i ON przebiegała bez zakłóceń. Nie było również kłopotów z uruchamianiem pojazdu. Podczas badań nie zaobserwowano żadnych ubytków oleju silnikowego. Średnie eksploatacyjne zużycie paliw na $100 \mathrm{~km}$ wynosiło:

- paliwo stanowiące mieszaninę estrów (75\% RME, 15\% CME, $10 \%$ estry zwierzęce) - około 111 ,

- $100 \%$ estry metylowe oleju rzepakowego - około 91 ,

- $\mathrm{ON}$ - około 71.

Z powyższych danych wynika, że większe zużycie paliwa wystąpiło $\mathrm{w}$ przypadku paliw estrowych w porównaniu z ON, mimo że paliwa estrowe charakteryzują się niż- szą emisją cząstek stałych, tlenków węgla i WWA. Prawdopodobną przyczyną większego zużycia paliwa jest wyższa zawartość tlenu w paliwach estrowych niż w ON. W procesie spalania paliw estrowych, ze względu na wyższą zawartość tlenu, uzyskuje się wyższe temperatury, co w konsekwencji powoduje większe zużycie paliwa estrowego niż ON w eksploatacji.

Analizując właściwości fizykochemiczne oleju silnikowego SAE 10W/40 API CF w trakcie eksploatacji samochodu osobowego AUDI A8 zasilanego paliwami estrowymi i ON, można stwierdzić, że:

- nie występowały gwałtowne spadki ani przyrosty lepkości kinematycznej zarówno podczas zasilania paliwami estrowymi, jak i ON,

- liczba zasadowa praktycznie nie uległa zmianie, niezależnie od rodzaju zasilania; te niewielkie spadki liczby zasadowej świadczą o prawidłowym i stopniowym zużywaniu 


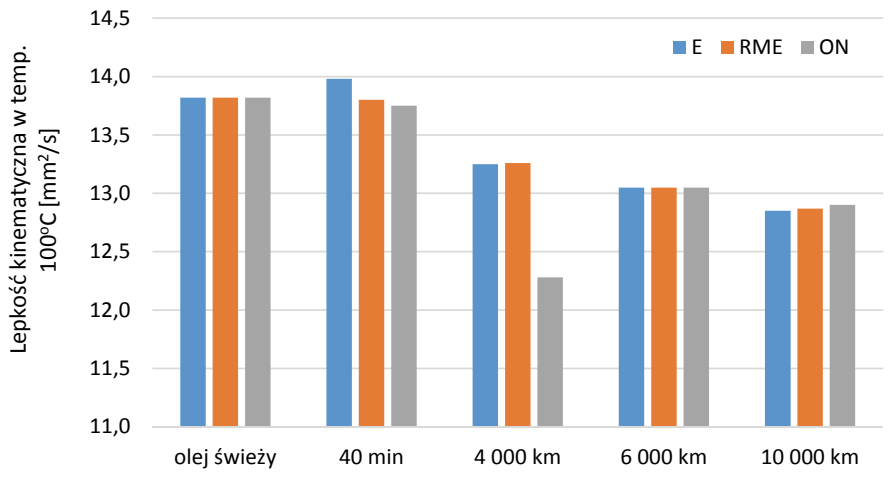

Rys. 2. Zmiana lepkości kinematycznej w temperaturze $100^{\circ} \mathrm{C}$ podczas zasilania paliwami estrowymi i ON

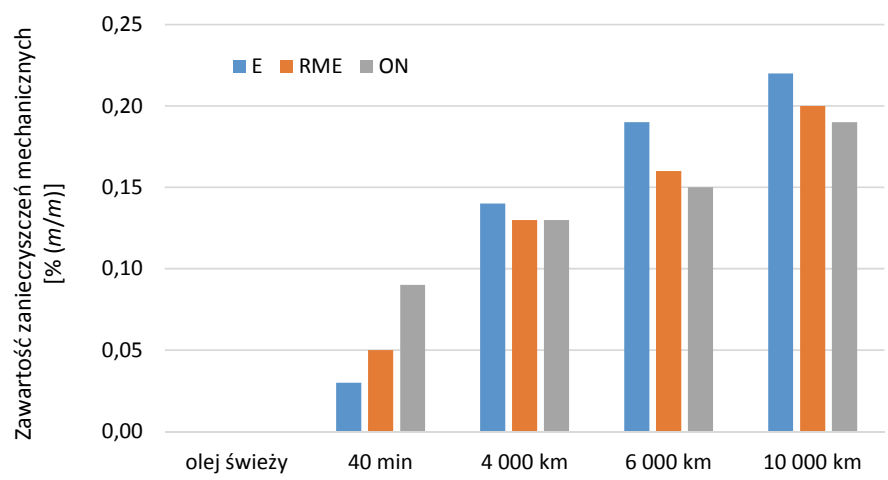

Rys. 4. Zawartość zanieczyszczeń mechanicznych podczas zasilania paliwami estrowymi i ON

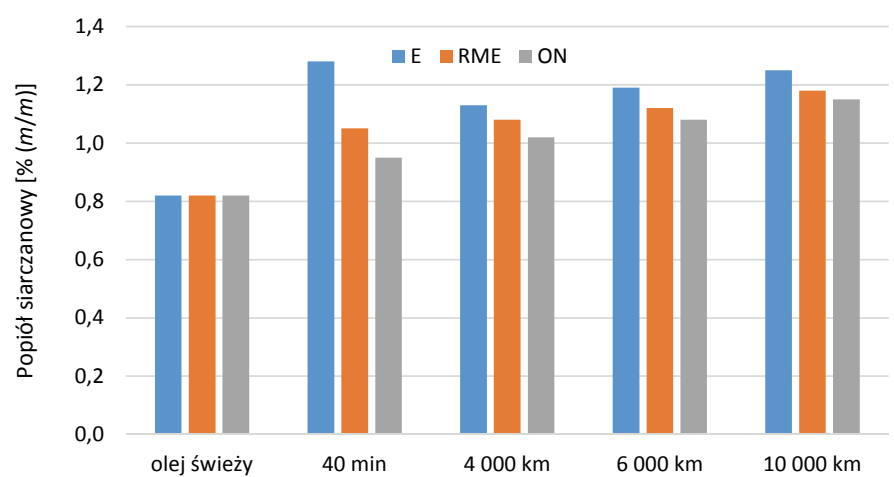

Rys. 6. Zmiana zawartości popiołu siarczanowego podczas zasilania paliwami estrowymi i ON

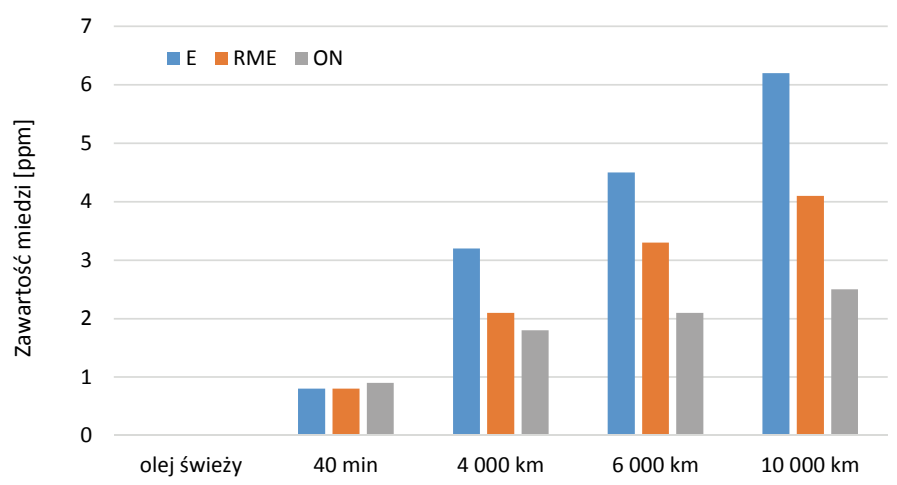

Rys. 8. Zawartość miedzi podczas zasilania paliwami estrowymi i ON

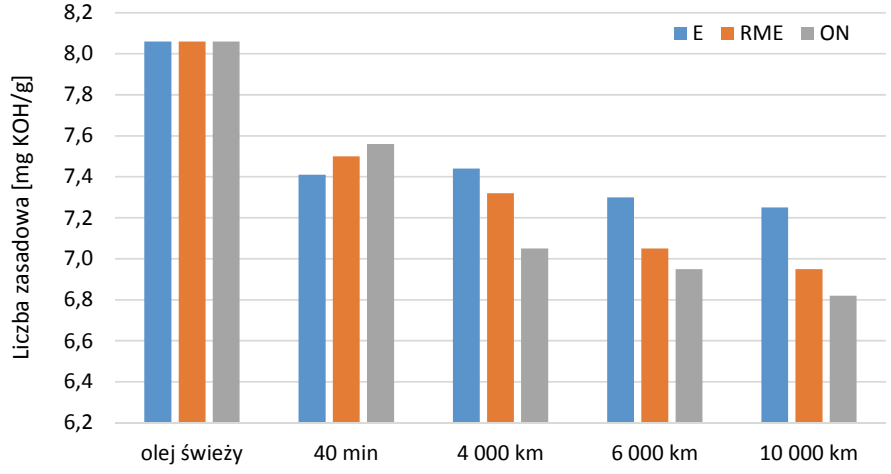

Rys. 3. Zmiana liczby zasadowej podczas zasilania paliwami estrowymi i ON

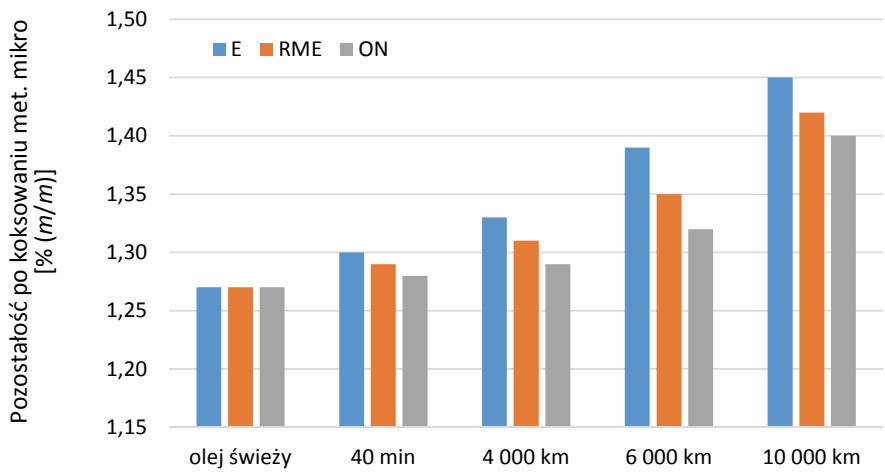

Rys. 5. Pozostałość po koksowaniu metodą mikro podczas zasilania paliwami estrowymi i ON

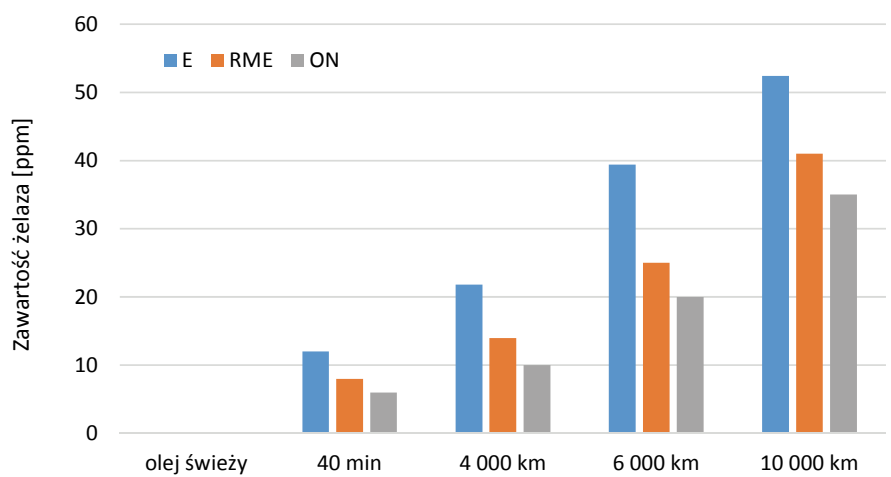

Rys. 7. Zawartość żelaza podczas zasilania paliwami estrowymi i ON

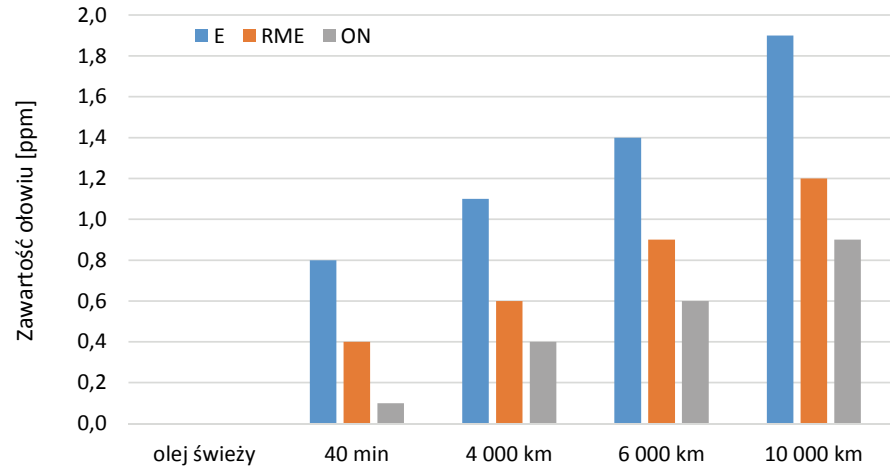

Rys. 9. Zawartość ołowiu podczas zasilania paliwami estrowymi i ON 
się dodatków zasadowych w procesie neutralizacji kwaśnych produktów utleniania oleju i spalania paliwa,

- zawartość zanieczyszczeń mechanicznych (osadów całkowitych) wzrastała stopniowo wraz z liczbą przejechanych kilometrów,

- uzyskane wartości pozostałości po koksowaniu i popiołu siarczanowego utrzymywały się na niskim poziomie i wskazują, że proces starzenia oleju zachodził bardzo powoli,
- w trakcie eksploatacji nie występowały gwałtowne przyrosty zawartości pierwiastków metalicznych pochodzących z elementów konstrukcji silnika (zwłaszcza żelaza i miedzi); niemniej jednak wyższe zawartości pierwiastków zaobserwowano dla obydwu paliw estrowych niż dla ON. W przypadku paliw estrowych wyższa zawartość tych pierwiastków cechowała paliwo stanowiące mieszaninę estrów niż czyste RME.

\section{Wnioski}

Na podstawie otrzymanych wyników badań w warunkach eksploatacji samochodu AUDI A8 podczas zasilania paliwami estrowymi i ON można stwierdzić, że:

- oceniane parametry badanego oleju w czasie eksploatacji samochodu AUDI A8 podczas zasilania paliwami estrowymi i ON uległy niewielkim zmianom i były adekwatne do liczby przejechanych kilometrów,

- w czasie badań podczas zasilania zarówno paliwami estrowymi, jak i ON olej silnikowy SAE 10W/40 charakteryzował się dobrą stabilnością termiczno-oksydacyjną, co stwierdzono na podstawie niewielkich zmian parametrów: lepkości kinematycznej, pozostałości po koksowaniu, osadów całkowitych i liczby zasadowej,

- olej silnikowy podczas badań eksploatacyjnych charakteryzował się dobrymi właściwościami przeciwutleniającymi, myjąco-dyspergującymi i przeciwzużyciowymi,

- uzyskane wyniki badań oleju silnikowego podczas zasilania paliwami estrowymi i ON wskazują na jego dalszą przydatność do eksploatacji,
- zarówno paliwo estrowe zawierające mieszaninę estrów metylowych, w tym estry metylowe oleju lniankowego, jak i paliwo estrowe zawierające 100\% estrów metylowych oleju rzepakowego nie wpłynęły negatywnie na procesy starzenia oleju silnikowego; zmiany we właściwościach fizykochemicznych były podobne w zbliżonych warunkach eksploatacji i przy podobnym przebiegu,

- zmiany we właściwościach fizykochemicznych oleju silnikowego cechowało również podobieństwo do zmian zaobserwowanych podczas zasilania samym ON (zawierającym około 7\% FAME) w podobnych warunkach eksploatacji i przebiegu.

Biorąc pod uwagę powyższe wnioski, można stwierdzić, że olej silnikowy SAE 10W/40 API CF może być stosowany do smarowania silników wysokoprężnych zasilanych paliwami estrowymi stanowiącymi czyste estry metylowe oleju rzepakowego lub mieszanką paliwową składająca się z estrów metylowych olejów roślinnych i tłuszczów zwierzęcych, w tym estrów metylowych oleju lniankowego.

Prosimy cytować jako: Nafta-Gaz 2017, nr 1, s. 43-48, DOI: 10.18668/NG.2017.01.05

Artykuł nadesłano do Redakcji 29.06.2016 r. Zatwierdzono do druku 11.10.2016 r.

\section{Literatura}

[1] Bystram K., Cygańska J., Jakubowski A., Klukowski A., Modzelewska K., Rutkowski A., Szczepańska H.: Poradnik inżyniera-przemyst tluszczowy. Warszawa, WNT, 1976.

[2] Kruczyński S., Kołodziejczyk K., Owczuk M., Orliński P., Mosio-Mosiewski J., Warzała M., Nosal H.: Ocena zastosowania estrów metylowych różnego pochodzenia $w$ silnikach o zapłonie samoczynnym. Zeszyty Naukowe Instytutu Pojazdów 2012, z. 2/88, s. 49-61.

[3] Mosio-Mosiewski J., Muszyński M., Nosal H., Warzała M.: Nowe możliwości wytwarzania biopaliw oraz biodegradowalnych środków smarowych w oparciu o surowce oleochemiczne. Środowisko i Rozwój 2008, nr 18(2), s. 31-40.
[4] Niewiadomski H.: Technologia tłuszczów jadalnych. Warszawa, WNT, 1993.

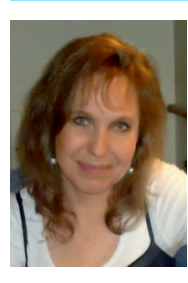

Mgr Monika ZIÓŁKOWSKA

Starszy specjalista badawczo-techniczny; zastępca

Kierownika Ośrodka Jakości

Przemysłowy Instytut Motoryzacji

ul. Jagiellońska 55

03-301 Warszawa

E-mail:m.ziolkowska@pimot.org.pl 